Archaeological Journal

\title{
St. Denis, Paris
}

\author{
J. H. Parker C.B., F.S.A.
}

To cite this article: J. H. Parker C.B., F.S.A. (1879) St. Denis, Paris, Archaeological Journal, 36:1, 231-236, DOI: $10.1080 / 00665983.1879 .10851881$

To link to this article: http://dx.doi.org/10.1080/00665983.1879.10851881

曲 Published online: 14 Jul 2014.

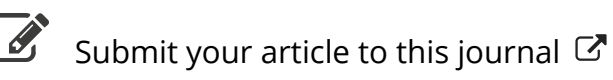

Q View related articles $₫$ 


\section{ST. DENIS, PARIS.}

BY J. H. PARKER, C.B., F.S.A.

It is not necessary to tell the members of the Archæological Institute that $\mathrm{S}^{\mathrm{t}}$. Denis is one of the turning points in the history of Architecture, and a very important one. Perhaps there is no other building about which there has been more discussion and dispute. It has been an object of interest to me for the last forty years; I have been there many times, and in company with some of the best archæologists in Europe, always discussing the doubtful points of its history in a friendly manner. I gave an account of it to the Society of Antiquaries ten years ago, not singly, but with other important buildings, in a paper on the "English Origin of Gothic Architecture," in which

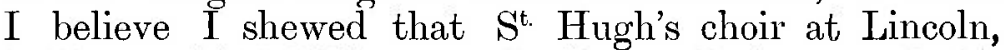
built A.D. 1192-1200, is really the earliest pure Gothic building in the world. This is the opposite of the Parisian view, which, to my surprise, appears to be adopted in the admirable lectures of my lamented friend, Sir Gilbert Scott. He could not really mean to adopt the whole of the Parisian view, that the present building is of the time of the great Abbe Suger, erected in 1160-1164: the fact is, that there is enough remaining of his time to shew that by far the greater part of the building is not of that time. Scott could only mean to adopt their view so far as this-that it is the first building in the north of Europe in which the pointed arch is used throughout; but the pointed arch alone does not make a Gothic building (as Scott has plainly shewn in other parts of his lectures). The main

1 Perhaps I may be allowed to repeat here a note that was printed in the Archcoologia, appertaining to my paper of June 3, 1869:- "On one of these occasions I was also accompanied by the Baron Von Quast, of Berlin, the Inspector of Monuments for Germany, and one of the best informed German archacologists, and by M. de Caumont, of Caen, the father of the modern school of Archæ. ology in France. 
characteristic of the style of the twelfth century (which in England is perhaps correctly called the Norman style, or more correctly the Anglo-Norman style) is massiveness, while the main characteristic of a building of the thirteenth century, when the pure Gothic style began, is lightness.

At $S^{t}$ Denis the building is of several dates; the original small crypt in which the remains of the kings of France were interred is very ancient, perhaps part of it as old as the time of the Carlovingian kings, as is said ; but this was far too small for the ideas of the twelfth century; an apse with a large aisle was added to it by Suger, and this remains unaltered, excepting that two pillars were introduced to carry two side columns of the choir above, and they cut through the vaults of Suger's work, being a century later. The mouldings of Suger's work are quite Norman; the only thing that differs from ordinary Norman work of that period is the regular use of the pointed arch. It is only a slight point, just a beginning, but may perhaps be the germ of the transitional period, which lasted half a century. The only part completed by Suger and now remaining is the crypt under the choir, and the lower part of the choir itself, the crypt under it. The record is that the ecclesia was dedicated in his time, but in the Latin of the twelfth century ecclesic usually means the choir only. The nave, if built at the same time, was called vestibula, but it was not often built at the same time. The architects of those days were very ambitious to outdo their rivals, and they commonly began a building on so large a scale that it would take two or three generations to complete the plan. So soon as the choir was ready the service could begin, and then the dedication took place. The part to be built next after the choir was usually the west end, with one or both of the western towers for the bells, and this was the case at $\mathrm{S}^{\mathrm{t} .}$ Denis ; but this part called the narthex, which is a large porch of two storeys, although begun by Suger, was not ready to be opened until the year 1201, when there was a grand ceremonial opening, at which King John of England and many other great personages were present. This work, which includes the west front, is not Gothic; it is advanced transitional, but still very heavy (the circular 
window is evidently much later $\left.{ }^{2}\right)$. Part of Notre Dame, at Paris, is of the same period, and quite as heavy as this narthex or more so. The probability is that the nave was not built until towards the middle of the thirteenth century. It is called a rebuilding, but was more probably a completion of the church by filling up the interval between the great narthex of the latter part of the twelfth century and the original choir and apse of the middle of that century. The nave belongs to the pure Gothic period, and is a fine example of it (built A.D. 1231 -1281). It seems evident that the walls of the choir were raised and the vault put on at this time, to make it correspond with the nave and with the fashion of the day. The work of Suger appeared clumsy and old fashioned to the architects of the nave, and the choir was considerably altered to make it correspond better with the new nave. The original arches of the choir and apse were low and narrow, not more than half the width of those of the nave. To produce a more harmonious whole, two of these narrow arches were made into one (that is, one on each side of the choir), and these arches that have been altered in this manner still have a crippled look. The introduction of the massive piers in the crypt before mentioned, to support a column on each side of the choir, make it evident that the central part of the choir and apse was not vaulted until that time, otherwise why is this additional strong support required? The flying buttresses or half-arches abutting against the exterior of the wall, to support the vault within, have been added at the same time. Buttresses of this description are essentially a feature of the Gothic styles; they are never found in Roman or Romanesque buildings, whether Norman or any other variety of the Romanesque styles, which vary considerably in some respects and in detail, but all agree in the same general character of massiveness. Some of the altars in the apsidal chapels of the choir have dates of the thirteenth century upon them. It is evident that great alterations were made at that time, as soon as the nave was completed, and that the whole choir and aisles were raised ten or twelve feet by the insertion of fresh

\footnotetext{
1 This frout has been so much mutilated and restored that no importance can be attached to it historically.
} 
stone work and shoring up the old vaults of the aisles. Professor Willis showed the Institute, at their first meeting at Canterbury, how ingeniously the same thing had been done there, by the evidence of the jointing of the masonry, all the new work being more finely jointed than the old work. The jointing of the masonry is often the best guide to the architectural history of a building.

I have said that $\mathrm{S}^{\mathrm{t} .}$ Denis was the earliest building in. the north of Europe in which the pointed arch was used throughout, but the pointed arch alone does not make the Gothic style; it was only one of the usual features of it, and not an indispensable one. The real characteristic of the two styles, or periods, is the massiveness of all the Romanesque styles, of which there is an infinite variety. They are all an imitation of the Roman style. There was in all countries a break, an interval of barbarism, after the fall of the Roman Empire; and when civilization began again, the inhabitants of each province imitated the Roman buildings that remained in that province. The Romanesque styles of Italy, of Germany, of Belgium and of Gaul are not the same in details, though they have the same general character, the debased Roman. In Gaul, each province has a Romanesque style of its own. The French Archæological Society, of which Arcisse de Caumont was the leader, set the example (since followed by this Institute) of making Archæological Excursions to different parts of the country, at first once a year only, latterly two or three times a year. In this manner they have examined the whole of that part of Gaul which is now called France. They found that in each province some particular Roman building still remaining in that district has been their model, and the peculiarities of that building have been the origin of the peculiarities of the styles of that province. For instance, in the province of which Vienne was the capital, and originally the seat of the Bishopric, the Roman building has fluted columns; the Bishopric was afterwards transferred to Lyons, and in the Cathedral of Lyons, which is of the thirteeth century, fluted columns were still used. The difference of style in the provinces of Champagne and of Burgundy is so marked, that all the churches on one side of the river which divides those provinces are of one character, and all those 
on the other side are of the other character, and both of these styles have been traced to a Roman building still remaining in each of them. It was found also, by this process of careful examination, by a party of well-informed and experienced antiquaries, coming chiefly from Normandy, that the buildings of Aquitaine have retained the pure Roman character much longer than any other part of France. At Carcassonne we have the first beginning of the revival of sculptured capitals, and that has the palm-leaf upon it, shewing its Oriental origin. In Perigord, which may be called a part of Aquitaine, the grand Cathedral of Perigueux, as built in the eleventh century, had pointed arches.

In many churches of Aquitaine, and in the west of France, of the early part of the twelfth century and even some of the eleventh, stone vaults were introduced in the original plan, the churches being purposely built long and narrow; and it is usually a long horizontal barrel vault but pointed, not round at the top, and when windows have to be introduced they also have pointed arches. Many of these churches are earlier than $\mathrm{S}^{\mathrm{t}}$. Denis.

$I$ have mentioned that in the Latin of the twelfth and thirteenth centuries, Ecclesia commonly means the choir only, and that so soon as the choir was ready for use it was consecrated, and modern authorities say that the church was consecrated at that date, whereas the nave was often not built for a century or more after that date (and sometimes not built at all) and is often of considerably later date than the choir; the next thing to be built after the choir is one of the western towers to hold the bells, then the transepts, if the church is cruciform with a central tower, and a low wall on each side of the nave. Wells Cathedral is a good example of this. The south tower of the west front is of the fifteenth century, although the choir is of the thirteenth; it is evident also, if people would attend to the construction of the walls, that the side walls of the nave were only built there also to the height of about six feet from the ground in the first instance, and the upper part of the walls added from time to time at intervals as the funds permitted.

It sometimes happens that the old west front of a previous building is preserved, when all the rest has been 
rebuilt, this is the case at Lincoln; the west front is of the eleventh and twelfth centuries, the original front is of the time of Remigius, very massive and plain, the rich doorways are insertions of Bishop Alexander about the middle of the twelfth century, the choir is the

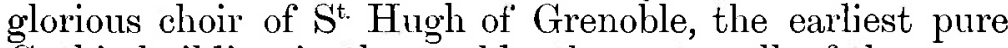
Gothic building in the world; the east wall of the great transept is also in part of his time, but a part only, that transept was not completed until thirty years afterwards. The great circular window of the north transept is about 1230. The nave has been built at intervals during the thirteenth century, there are varieties of detail in different parts, it was begun at both ends, so that the central part is the latest. In Carlisle Cathedral two bays of the nave only hare been built. At Cologne Cathedral the choir is thirteenth, one of the western towers is fourteenth, and the nave is of the nineteenth. The original plans were preserved by accident but have not been followed, the modern architects thought they could improve upon them, and they have done the opposite, the central tower is absurdly too small for the place that it occupies.

The present Bishop of Truro seems to have set the example of following the plans of the middle ages in not attempting to do too much at once, but having faith that his successors will complete the good work begun. Father Benson, of Cowley, in Oxford, has followed the same plan, he has built a fine choir only, leaving the nave to be built when funds come in. Let us hope that these examples will be followed. 